\title{
Resultat av tuberkulosebehandling i Norge 1995
}

\author{
Einar Heldal \\ Det sentrale tuberkuloseregister, Statens helseundersøkelser \\ Kontaktadresse: Statens helseundersøkelser, Postboks 8155 Dep, 0033 Oslo \\ Tel. 222076 55, Fax 2220 16 73, e-post: eiheldal@online.no
}

\begin{abstract}
SAMMENDRAG
I tillegg til insidens og mortalitet, har andelen pasienter som fullfører tuberkulosebehandlingen («helbredelsesrate») nylig blitt anbefalt av IUATLD og WHO som en indikator for vurdering av tuberkulosekontrollen. I denne studien ble resultatet av tuberkulosebehandlingen vurdert hos alle pasienter med dyrkningsbekreftet lungetuberkulose meldt til Det sentrale tuberkuloseregister i 1995. Av 101 pasienter fullførte 77 behandlingen («helbredelsesrate» 76\%), 9 forsvant, 14 døde og én fortsatte å være smitteførende. De fleste (7 av 9) som forsvant var født utenfor Norge, mens de fleste (13 av 14) som døde var født i Norge.

Helbredelsesraten i Norge er langt dårligere enn WHOs anbefalinger ( $85 \%$ helbredelsesrate) og resultatene oppnådd i enkelte andre land som Nederland. Vurdering av behandlingsresultat er en viktig del av tuberkuloseovervåkningen. Tiltak bør iverksettes for å redusere mortaliteten og andelen pasienter som forsvinner før avsluttet behandling.
\end{abstract}

Heldal E. Results of tuberculosis treatment in Norway 1995. Nor J Epidemiol 1997; 7 (2): 231-233.

\section{ENGLISH SUMMARY}

In addition to incidence and mortality the proportion of patients who complete tuberculosis treatment (cure rate) has recently been recommended by the IUATLD and WHO as an indicator in assessing tuberculosis control. In the present study the result of tuberculosis treatment was assessed in all patients with culture confirmed pulmonary tuberculosis notified to the National Tuberculosis Register in 1995. Out of 101 patients 77 completed treatment (cure rate 76\%), 9 disappeared, 14 died and one continued to be contagious (failure case). Most of those who disappeared (7 out of 9) were born outside Norway, while most of those who died (13 out of 14) were born in Norway.

The cure rate in Norway was far below the level of $85 \%$ recommended by WHO, and achieved in countries like the Netherlands. The assessment of treatment result is an important component of tuberculosis surveillance. Action should be taken to reduce mortality and the proportion of patients who disappear from treatment.

\section{INNLEDNING}

Tuberkulosesituasjonen har tradisjonelt blitt vurdert ved insidens og mortalitet (1-5). De siste årene har imidlertid manglende fullført behandling, eventuelt med utvikling av resistente basiller, blitt identifisert som et økende problem både i u-land og i-land, blant annet i USA (6). Den internasjonale tuberkulose- og lungesykdomsunionen (IUATLD) utviklet i 1980årene en ny effektiv modell for tuberkulosekontroll, der behandlingen bestod av en kombinasjon av potente tuberkulosemedikamenter i en to-måneders startfase under direkte supervisjon av helsepersonell. En styrking av laboratorienettverket for diagnostikk, forsyningssystemet for medikamenter og sentral oppfølging inngikk også i modellen. Kohortanalyse av behandlingsresultat ble brukt til å vise at opptil $80 \%$ av pasientene ble helbredet $\mathrm{i}$ enkelte modell-land, når grupper av pasienter som ble registrert i løpet av en definert periode ble vurdert ved behandlingstidens slutt etter 6-8 måneder (7). Senere har Verdens helseorganisasjon (WHO) anbefalt den samme modellen og angitt som mål at $85 \%$ av de som blir registrert skal helbredes (8). IUATLD, WHO og Den nederlandske 
tuberkuloseforeningen (KNCV) har nylig utarbeidet anbefalinger for enhetlige meldingssystemer i Europa der behandlingsresultatet inngår (9).

I Norge har resultatet av tuberkulosebehandling på landsbasis ikke blitt vurdert tidligere. For pasienter som ble meldt fra og med 1. januar 1996 inngår resultat av behandling som en del av meldingssystemet. Et eget skjema sendes ut til kontrollerende lege ni måneder etter behandlingsstart (10). Norge er foreløpig det eneste landet i Europa der behandlingsresultatet er meldingspliktig, men slik registrering gjennomføres på frivillig basis over hele landet $i$ noen få land som Nederland, Tsjekkia og Slovakia.

$\mathrm{Vi}$ innhentet resultat av behandling hos pasienter som ble meldt i 1995.

\section{FORMÅL}

Vurdere resultatet av tuberkulosebehandlingen hos pasienter meldt i 1995.

\section{MATERIALE OG METODER}

Pasienter meldt til Det sentrale tuberkuloseregister i løpet av året 1995 med lungetuberkulose der dyrkning hadde bekreftet funn av Mycobacterium tuberculosis i prøver fra luftveiene, ble inkludert. Hvis ikke opplysninger om behandlingsresultat fantes i mottatte skjemaer, ble et eget spørreskjema sendt til kontrollerende lege. Ved manglende svar ble telefonisk purring foretatt. Kategorier for behandlingsresultat fulgte IUATLDs definisjoner (11):

- Fullført behandling. Denne kategorien ble delt i to: med eller uten negativ bakteriologisk prøve ved avsluttet behandling (etter 6-9 måneder) som bevis på at basillene hadde forsvunnet, og pasienten var helbredet. Disse to gruppene sammen utgjør «helbredelsesrate».

- Fortsatt positiv bakteriologisk prøve etter fem måneders behandling betegnes «failure rate» og kan skyldes resistente stammer og/eller at pasienten ikke har tatt medikamentene som foreskrevet.

- Forsvunnet brukes hvis pasienten har blitt angitt å ha vært borte fra behandlingen i to måneder eller mer.

- Død omfatter både dødsfall på grunn av tuberkulose og av annen årsak. Her inkluderes også pasienter som oppdages ved obduksjon.

\section{RESULTAT}

Tilsammen 236 tuberkulosepasienter ble meldt i 1995, derav 146 med lungetuberkulose (12). Av disse hadde 101 dyrkningsverifisert tuberkulose. $76 \%$ ble helbredet (tabell 1). Av ni pasienter som forsvant fra behandlingen var syv født utenfor Norge, mens tretten av fjorten som døde var norskfødte. Seks av fjorten som døde hadde ikke fått tuberkulosebehandling. Gjennomsnittsalder var høyere for de som døde enn for de som ble helbredet.
Tabell 1. Resultat av tuberkulosebehandling hos pasienter som ble meldt med dyrkningsbekreftet lungetuberkulose i 1995 .

\begin{tabular}{lrrr}
\hline Resultat & Antall & \multicolumn{2}{c}{ Alder (SD) } \\
\hline Fullført med negativ bakteriologi & 41 & 54,9 & $(20,8)$ \\
Fullført uten negativ bakteriologi & 36 & 51,2 & $(22,9)$ \\
Fortsatt positiv bakteriologi & 1 & - & - \\
Forsvant fra behandlingen & 9 & $46,6 \quad(22,7)$ \\
Døde & 14 & $79,1 \quad(12,7)$ \\
Totalt & 101 & $56,0 \quad(22,7)$ \\
\hline
\end{tabular}

Ved logistisk regresjon var verken kjønn eller alder signifikant relatert til helbredelse. Når død var avhengig variabel, kom alder ut som signifikant prediktor $(\mathrm{p}=0,0031)$.

Hos én pasient endret basillene seg fra fullt følsomme til multiresistente (både mot isoniazid og rifampicin) under pågående behandling. Ufullstendig behandlingskombinasjon i startfasen og manglende compliance under behandlingen kan forklare dette.

\section{DISKUSJON}

For første gang er resultatet av tuberkulosebehandling på landsbasis vurdert. Studien viser at behandlingsresultatet i Norge ikke er tilfredsstillende, idet en fjerdedel av pasientene ikke ble helbredet, deriblant 6 som døde før behandling ble startet.

Vi valgte i studien bare å følge pasienter med dyrkningsverifisert lungetuberkulose fordi diagnosen var sikker i disse pasientene og siden de er smittsomme.

Et alternativ var å inkludere også pasienter med positiv direkte mikroskopi av ekspektorat. Funn av syrefaste staver i direkte mikroskopi tyder på tuberkulose, men uten dyrking kan ikke typen (species) bestemmes, slik at atypiske mykobakterier kan utelukkes. I 1995 utgjorde pasienter med lungetuberkulose meldt med positiv direkte mikroskopi, men negativ dyrkningsprøve, en gruppe på 12 pasienter, så få at vi ikke mener våre konklusjoner ville blitt endret.

Bare tre europeiske land har publisert nasjonale tall for helbredelsesrater i 1994. Her er utvalget nye pasienter med lungetuberkulose bekreftet ved direkte mikroskopi: Nederland 81\% (13), Tsjekkia 73\% (9) og Slovakia 96\% (9). Mindre studier finnes fra Tyskland 1994-95 (68\%) (9), Italia 83\% (14) og Paris 66\% (15). I IUATLDs modell-land (Tanzania, Nicaragua, Malawi, Benin) lå helbredelsesraten på slutten av 1980-tallet på 75-80\% (7) for hele landet blant nye pasienter med lungetuberkulose bekreftet ved direkte mikroskopi.

Den relativt lave helbredelsesraten i Norge skyldes delvis at mange dør.

Ved vurdering av hva som skjedde med pasientene som ble meldt i løpet av ett år, skal også pasienter som 
aldri startet på behandling inkluderes, selv om det virker selvmotsigende å snakke om behandlingsresultat av pasienter som aldri startet behandling. Dette er en viktig gruppe idet de manifesterer en svikt i tuberkulosekontrollen (9).

Tidligere studier i Oslo/Akershus har vist at det vesentlig er eldre norskfødte pasienter som dør og at halvparten av de som døde med aktiv tuberkulose først fikk stilt diagnosen ved obduksjon (16). Våre tall bekrefter disse funnene.

Den andre hovedårsaken til den lave helbredelsesraten er at mange forsvinner fra behandlingen. Årsakene til compliance-problemer er mange og sammen- satte: blant annet koordinering mellom sykehus og kommune/bydel, språkproblemer, ulike former for sosiale problemer $(17,18)$.

\section{KONKLUSJON}

Vurdering av resultatet av tuberkulosebehandling er en viktig del av tuberkuloseovervåkningen. Tallene fra 1995 viser at Norge med 76\% helbredelsesrate er langt fra WHOs anbefalte nivå på $85 \%$. Sammenlignet med andre land har norske pasienter en høy andel som dør med aktiv tuberkulose og en høy andel som forsvinner fra behandlingen.

\section{REFERANSER}

1. Styblo K. Epidemiology of tuberculosis. Royal Netherlands Tuberculosis Association (KNCV). Selected papers vol. 24, 1994.

2. Raviglione M, Snider DE, Kochi A. Global epidemiology of tuberculosis. J Am Med Assoc 1995; 273: 220-226.

3. Raviglione MC, Sudre P, Rieder HL, Spinaci S, Kochi A. Secular trends of tuberculosis in Western Europe. Bull WHO 1993; 71: 297-306.

4. Bjartveit K. The tuberculosis situation in Norway. Scand J Respir Dis 1978; Suppl 102: 28-34.

5. Heldal E, Bjartveit K, Tverdal A. Utviklingen av tuberkulose i Norge - har nedgangen stanset? Tidsskr Nor Lageforen 1995; 115 (27): 3390-3393.

6. Brudney K, Dobkin J. Resurgent tuberculosis in New York City. Am Rev Respir Dis 1991; 144: 745749.

7. Enarson DA. Principles of IUATLD collaborative tuberculosis programmes. Bull Int Union Tuberc Lung Dis 1991; 66: 195-200.

8. Global tuberculosis control. WHO Report 1997. WHO/TB/97.225. Geneva, 1997.

9. Veen J, Raviglione M, Rieder H, Migliori GB, Graf P, Grzemska M, Zalesky R. Standardized tuberculosis treatment outcome monitoring in Europe. 1997 (submitted).

10. Bjartveit K. Kontroll av tuberkulose. Håndbok for kommunehelsetjenesten. Statens helseundersøkelser/ Statens helsetilsyn. Oslo, 1996.

11. Enarson DA, Rieder H, Arnadottir T. Tuberculosis guide for low-income countries, 3rd edition, Paris: IUATLD, 1994.

12. MSIS-rapport 37/1996. Statens institutt for folkehelse.

13. Veen J, Kalisvaart NK. Index tuberculosis KNCV, Den Haag, 1997.

14. Migliori GB, Ambrosetti M, Besozzi G, et al. Cohort analysis of anti-tuberculosis treatment results in Italy. Progress report, First research project tuberculosis, Instituto Superiore di sanita. Rapporti ISTSAN 1997; 97: 141.

15. Cruz AG, Gulbaran Z, Enarson DA. Cohort evaluation of treatment results. Tub Lung Dis 1995: 76 (suppl 2): 80.

16. Naalsund A, Heldal E, Johansen B, Kongerud J, Boe J. Deaths from pulmonary tuberculosis in a lowincidence country. J Intern Med 1994; 236: 137-142.

17. Sbarbaro JA. Compliance: inducements and enforcements. Chest 1979; 6 (suppl): 750-756.

18. Bayer R, Wilkinson D. Directly observed therapy for tuberculosis: history of an idea. Lancet 1995; 345: $1545-1548$. 